\title{
Tata Laksana Anestesi pada Sectio Caesar Pasien G4P3A0H3 gravid aterm 38-39 minggu dengan Hipertiroid
}

\author{
Muhammad Zulfadli Syahrul $^{1}$, Nabila Jasmine ${ }^{2}$
}

\begin{abstract}
Abstrak
Hipertiroidisme merupakan peningkatan abnormal konsentrasi serum dari hormon tiroid bebas. Kelainan tiroid merupakan abnormalitas endokrin kedua tersering dalam masa kehamilan dan telah diketahui bahwa disfungsi tiroid dapat mengakibatkan efek yang merugikan baik bagi ibu maupun janin. Pasien hipertiroid memiliki risiko khusus apabila menjalani operasi, yakni badai tiroid, yang dapat dieksaserbasi oleh beberapa kondisi termasuk anestesia, pembedahan, perdarahan, kehamilan dan melahirkan anak (baik kelahiran normal ataupun dengan operasi caesarean). Pada pasien yang diketahui mengidap hipertiroidisme, terdapat beberapa pertimbangan dan tindakan khusus yang harus dilakukan, baik pada fase preoperatif, intraoperatif maupun postoperatif. Laporan kasus ini akan membahas pelaksanaan anestesi dan pembedahan pada seorang pasien wanita (42 tahun) dengan kehamilan cukup bulan dan riwayat hipotiroidisme terkontrol yang menjalani sectio caesarea di RSUP Dr. M. Djamil Padang.
\end{abstract}

Kata kunci: hipertiroid, kehamilan, anestesi, pembedahan, sectio caesarea, badai tiroid

\begin{abstract}
Hyperthyroidism is defined as an abnormal increase in the serum concentration of unbound or free thyroid hormones. The thyroid disorders are the second most common endocrine abnormality during pregnancy and it is well known that thyroid dysfunction during pregnancy can have deleterious effects on both mother and fetus. Hyperthyroid patients face a certain risk during surgeries, namely thyroid storm, which could be exacerbated by conditions including anesthesia, surgery, hemorrhage, pregnancy, and childbirth (both normal labor and caesarean delivery). Therefore, on patients with hyperthyroidism, there are certain considerations and measures that needs to be taken during preoperative, intraoperative, and postoperative phases of surgery. This case reported focuses on the anesthetic and surgical process of a 42-year-old female patient with aterm pregnancy and history of controlled hyperthyroidism undergoing caesarean section at RSUP Dr. M. Djamil Padang.
\end{abstract}

Keywords: hyperthyroid, pregnancy, anesthesia, surgery, caesarean section, thyroid storm

Affiliasi penulis: 1. Bagian Anestesiologi Fakultas Kedokteran Universitas Andalas (FK Unand), 2. Prodi Profesi Dokter FK Unand Korespondensi: Muhammad Zulfadli Syahrul

mzulfadlisyahrul@med.unand.ac.id

\section{PENDAHULUAN}

Hipertiroidisme merupakan peningkatan abnormal konsentrasi serum dari hormon tiroid bebas. Hipertiroidisme bermanifestasi sebagai kondisi fisiologis yang didominasi peningkatan laju metabolik. ${ }^{1}$ Manifestasi klinis dari kelebihan konsentrasi hormon tiroid meliputi penurunan berat badan, intoleransi panas, kelemahan otot, diare, reflek hiperaktif, dan kecemasan. Tremor, eksoftalmus dan goiter dapat terlihat, terutama apabila disebabkan oleh penyakit Graves'. Fibrilasi atrium onset baru merupakan presentasi klasik hipertiroidisme, tetapi tanda-tanda kardiak juga mencakup sinus takikardi dan gagal jantung kongestif. Diagnosis hipertiroidisme dikonfirmasi dengan uji fungsi tiroid abnormal, yang mungkin dapat meliputi peningkatan T4 serum dan T3serum dan penurunan kadar $\mathrm{TSH}^{2}{ }^{2}$

Pasien dengan disfungsi tiroid cukup banyak prevalensinya pada populasi umum. Ada banyak efek hormon tiroid pada tubuh, efek disfungsi tiroid sangat 
beragam dan secara signifikan memperumit prosedur pembedahan dan pemulihan postoperatif. ${ }^{3,4}$

Dalam masa kehamilan, kelainan tiroid merupakan abnormalitas endokrin kedua tersering dan telah diketahui bahwa disfungsi tiroid dapat mengakibatkan efek yang merugikan baik bagi ibu maupun janin. ${ }^{5}$

Pasien hipertiroid memiliki risiko khusus apabila menjalani operasi, yaknithyroid storm, yang dapat dieksaserbasi oleh beberapa kondisi termasuk anestesia, pembedahan, perdarahan, kehamilan, dan melahirkan anak (baik kelahiran normal ataupun dengan operasi caesarean). Thyroid storm terjadi pada $2 \%$ hingga $4 \%$ pasien hamil dengan hipertiroidisme. $^{1}$

Persiapan preoperatif yang adekuat harus dilakukan untuk meminimalisir risiko thyroid storm perioeratif. Apabila memungkinkan, operasi sebaiknya ditunda sampai pasien eutiroid. Anestesiologis hendaknya mempersiapkan diri untuk menatalaksana thyroid storm perioeratif. ${ }^{1,2}$

\section{KASUS}

Seorang pasien wanita, berusia 42 tahun, dirawat di RSUP Dr. M. Djamil Padang dengan diagnosis utama $\mathrm{G}_{4} \mathrm{P}_{3} \mathrm{~A}_{0} \mathrm{H}_{3}$ gravid aterm 38-39 minggu dan sudah pernah menjalani pembedahan sectio caesarea (SC) sebelumnya sebanyak satu kali pada tahun 2013 atas indikasi preterm premature rupture of membranes dan disproporsi sefalopelvik. Pasien dikenal dengan riwayat hipertiroid. Pada pasien dilaksanakan pembedahan sectio caesarea transperitoneal profunda (SCTPP) elektif.

Anamnesis didapatkan pasien tidak haid sejak sembilan bulan terakhir. Tidak ada nyeri punggung menjalar ke ari-ari, keluarnya lendir bercampur darah dari kemaluan, darah yang banyak dari kemaluan, maupun air-air yang banyak dari kemaluan. Pasien mengalami gangguan buang air besar berupa feses yang lunak lima bulan yang lalu, jumlah dan frekuensi dalam batas normal.

Pasien menderita hipertiroid sejak dua tahun yang lalu dan telah terkontrol dengan obat antitiroid. Pasien tidak memiliki riwayat penyakit diabetes mellitus, hipertensi, penyakit jantung, hepar, maupun ginjal. Pasien juga tidak memiliki riwayat alergi makanan maupun obat. Pasien tidak ada mengeluhkan berdebar-debar sejak minum obat. Tidak ada riwayat penyakit menular, kejiwaan dan keturunan pada anggota keluarga.

Pada pemeriksaan fisik, kondisi umum pasien tampak sakit sedang dan sadar. Tekanan darah, nadi, nafas dan suhu pasien dalam batas normal. Hasil pemeriksaan fisik kulit dalam batas normal. Kepala normocephal. Tidak teraba pembesaran kelenjar getah bening. Rambut hitam dan tidak mudah rontok. Kedua konjungtiva tidak anemis, sklera tidak ikterik, tidak terlihat eksoftalmus. Telinga dalam batas normal. Hidung dalam batas normal. Grading tonsil $\mathrm{T}_{1}-\mathrm{T}_{1}$. Bentuk dada normochest, simetris kiri dan kanan pada pemeriksaan statis dan dinamis, dan dari auskultasi suara napas bronkovesikular, tidak ada rhonki maupun wheezing pada kedua lapangan paru. Cor dalam batas normal, tidak terdengar adanya bising pada auskultasi, dengan risiko 0,9\% komplikasi kardiovaskular perioperatif berdasarkan Lee Revised Cardiac Index (risiko kelas 2). Abdomen tampak membuncit, sesuai dengan usia kehamilan gravid aterm, fundus uteri teraba 3 jari di bawah processus xyphoideus, tidak ada his. Denyut jantung janin 130-140 kali per menit. Hepar dan lien tidak teraba, bising usus positif dengan frekuensi normal. Pada pemeriksaan ekstremitas, didapatkan akral hangat dan perfusi baik, dan didapatkan tremor halus pada kedua tangan. Pada pemeriksaan genitalia, vulva/uretra tenang, perdarah pervaginam tidak ada.

Pemeriksaan laboraturium menunjukkan pemeriksaan darah rutin dengan hasil dalam batas normal. Prothrombin time dan APTT dalam batas normal. Glukosa darah sewaktu dalam batas normal. Kadar ureum dan kreatinin darah dalam batas normal. Kadar elektrolit kalsium, natrium, kalium dan klorida serum dalam batas normal. Bilirubin direk dan indirek dalam batas normal. SGOT dan SGPT dalam batas normal. Adapun protein total pasien ini menunjukkan hasil 6,2 $\mathrm{g} / \mathrm{dl}$ dengan albumin 3,5 g/dl dan globulin 2,7 $\mathrm{g} / \mathrm{dl}$, hasil tersebut menunjukkan interpretasi protein total dan albumin yang di bawah nilai rujukan. Hasil pemeriksaan hormon tiroksin $\left(T_{4}\right)$ bebas $10,53 \mathrm{pmol} / \mathrm{L}$, dan kadar $\mathrm{TSH} 10,68 \mu \mathrm{lU} / \mathrm{mL}$, sehingga $\mathrm{FT}_{4}$ dan $\mathrm{TSH}$ dalam batas normal. 
Pasien telah menjalani pemeriksaan lainnya seperti EKG dengan kesan sinus rythm, foto polos toraks dengan hasil dalam batas normal,dan ultrasonografi serta kardiotokografi. Pasien dikategorikan sebagai pasien ASA II, karena adanya riwayat hipertiroid, dengan kondisi terkontrol dengan obat.

Selama masa perawatan, pasien ditatalaksana dengan obat antitiroid berupa propylthiouracil (PTU) 2 x 50 mg, sesuai anjuran Bagian IImu Penyakit Dalam, dan sudah mengonsumsi PTU dalam dosis tersebut selama satu bulan terakhir. Sebelumnya pasien telah mengonsumsi PTU dalam dosis $2 \times 100 \mathrm{mg}$ selama kurang lebih dua tahun.

Pada persiapan preoperatif, pasien mengikuti protokol tatalaksana krisis tiroid sesuai anjuran Bagian IImu Penyakit Dalam, yakni saat menjelang operasi dilakukan loading PTU 600 mg, kemudian satu jam setelahnya Lugol 10 tetes. Selanjutnya diberikan PTU $4 \times 200 \mathrm{mg}$, Lugol $4 \times 10$ tetes, Dexamethasone $4 \times 10$ mg intravena, dan Propanolol $4 \times 20$ mg per oral. Tiga puluh menit menjelang operasi, pasien juga diinjeksikan Ceftriaxone $2 \mathrm{~g}$. Pasien puasa delapan jam menjelang operasi. Untuk operasinya, dipersiapkan darah sebanyak 2 unit PRC Dipersiapkan pula ruang rawatan intensif (ICU) sebagai persiapan bila terjadi krisis tiroid selama masa operasi dan postoperatif, serta untuk pemantauan post operatif.

Operasi dilaksanakan sehari setelah pasien mulai dirawat, yaitu SCTPP dan fimbrektomi tuba dextra dan sinistra atas indikasi jumlah anak cukup. Sebelum dilakukan pembiusan, diberikan premedikasi intravena Ondansetron $4 \mathrm{mg}$, dexametasone 2 ampul Pembiusan dilakukan dengan teknik regional jenis spinal, padalevel ketinggian blokade $L_{3-4}$, dengan jarum spinal $27 \mathrm{G}$, dan obat marcain $10 \mathrm{mg}+$ fentanyl 25 mcg dengan hasil total blok. Obat-obatan lain yang diberikan midazolam $2 \mathrm{mg}+$ fentanyl $50 \mathrm{mcg}$ setelah bayi lahir. Setelah operasi, pasien dipindahkan ke Ruang Observasi Intensif (ROI) dengan. Di ROI, pasien kembali mendapatkan obat-obatan PTU, lugol, dan propanolol secara enteral. Secara parenteral, pasien diberikan pula obat-obatan ceftriaxon, ranitidin, paracetamol, asam traneksamat, vitamin $\mathrm{K}$ dan dexametason.

\section{PEMBAHASAN}

Telah dilaporkan kasus seorang wanita berusia 42 tahun, dengan diagnosis utama $\mathrm{G}_{4} \mathrm{P}_{3} \mathrm{~A}_{0} \mathrm{H}_{3}$ gravid aterm 38-39 minggu dan diagnosis sekunder hipertiroid terkontrol.

Kehamilan manusia normalnya adalah keadaan eutiroid dengan konsentrasi serum dari $T_{4}$ dan $T_{3}$ bebas yang normal, walaupun terdapat peningkatan konsentrasi serum dari TBG dan $\mathrm{T}_{4}$ total, serta beberapa perubahan fisiologi tiroid dalam tubuh yang diatur oleh aksis hypothalamic-pituitary-thyroid (HPT).Dalam masa kehamilan, hipertiroid muncul dari etiologi-etiologi yang sama dengan hipertiroid pada pasien di luar kehamilan. Penyebab utama hipertiroid pada kehamilan adalah penyakit Graves', dengan prevalensi $0,2 \%$, yang mana lebih rendah daripada populasi normal. Hal ini mungkin dikarenakan efek menguntungkan dari imunotoleransi pada kehamilan terhadap kelainan-kelainan autoimun seperti penyakit Graves'. ${ }^{1}$ Kelainan tiroid tetap merupakan abnormalitas endokrin kedua tersering selama masa kehamilan dan telah diketahui bahwa disfungsi tiroid dapat mengakibatkan efek yang merugikan baik bagi ibu maupun janin. 5,6

Thyroid storm adalah suatu eksaserbasi yang mengancam nyawa atau dekompensasi dari kondisi hipertiroid yang telah ada sebelumnya. Thyroid storm adalah sebuah diagnosis klinis berdasarkan gejalagejala dan tanda-tanda berikut: (1) demam, (2) gangguan mental dan emosional, (3) takikardi, (4) takipneu, (5) diaforesis, (6) diare. Apabila tidak ditatalaksana, thyroid storm dapat berprogresi menjadi koma, kegagalan sistem multiorgan, dan kematian. Dahulu, tingkat mortalitas kondisi ini mendekati 100\%, tetapi terapi yang lebih baik telah menurunkan angkanya menjadi kurang dari $20 \%$. Deteksi dini dan tatalaksana agresif sangat penting dalam membatasi morbiditas dan mortalitas. ${ }^{1,7}$

Mekanisme terjadinya thyroid stormbelum diketahui pasti. Beberapa teori menghubungkan kejadian ini dengan peningkatan sekresi dan sirkulasi hormon tiroid. Sekresi katekolamin mungkin juga dapat memainkan peranan dalam terjadinya thyroid storm. Pada sebagian besar kasus, thyroid storm dihubungkan dengan peristiwa pencetus (stres fisik 
atau mental yang berat) pada pasien dengan hipertiroidisme yang tidak terkontrol atau tidak ditatalaksana dengan baik. Beberapa peristiwa yang dapat mencetuskan thyroid storm: pembedahan, kelahiran anak, trauma, agen kontras teriodinisasi, terapi dengan iodide ${ }^{131} \mathrm{I}$, stres emosional, emboli paru, stroke, infeksi, ketoasidosis diabetik, hipoglikemia, gagal jantung kongestif, dan infark usus. ${ }^{1,8}$

Pasien memiliki beberapa faktor risiko yang dapat menjadi peristiwa pencetus thyroid storm ini. Namun, saat akan dilakukan operasi, pasien berada dalam kondisi eutiroid, karena pasien rutin mengonsumsi obat antitiroid berupa PTU sejak dua tahun terakhir.

Oleh dokter spesialis penyakit dalam, sebagai bagian dari preparasi preoperatif, pasien dianjurkan melanjutkan konsumsi PTU 2 × 50 mg. Kemudian, pasien mengikuti protokol tatalaksana krisis tiroid sesuai anjuran bidang IImu Penyakit Dalam, yakni saat menjelang operasi dilakukan loading PTU $600 \mathrm{mg}$, kemudian satu jam setelahnya Lugol 10 tetes. Selanjutnya diberikan PTU 4 × 200 mg, Lugol 4 × 10 tetes, Dexamethasone $4 \times 10 \mathrm{mg}$ intravena, dan Propanolol 4 × $20 \mathrm{mg}$ per oral.

Tatalaksana medis hipertiroidisme adalah dengan obat-obatan yang menghambat sintesis hormon tiroid (misalnya PTU, methimazole), mencegah pelepasan hormon (misalnya iodida kalium, natrium) atau menyamarkan tanda-tanda overaktivitas adrenergik (seperti propranolol). Pasien hipertiroid juga memiliki defisiensi glukokortikoid relatif dan sebaiknya diberi suplementasi. Sebagai tambahan, meskipun antagonis beta-adrenergik tidak memengaruhi fungsi kelenjar tiroid, obat-obat tersebut menurunkan konversi perifer dari $\mathrm{T}_{4}$ menjadi $\mathrm{T}_{3}$. lodin radioaktif menghancurkan fungsi sel tiroid dan dapat menyebabkan hipotiroidisme. lodin radioaktif tidak direkomendasikan bagi pasien-pasien yang sedang mengandung. Adapun modalitas surgikal, seperti tiroidektomi subtotal, dapat digunakan sebagai alternatif jika terapi medis gagal, tetapi jarang. Terapi tersebut hanya digunakan pada pasien-pasien dengan goiter multinodular toksik yang besar atau adenoma toksik soliter. Penyakit Graves' biasanya ditatalaksana dengan obat-obatan antitiroid atau iodin radioaktif. ${ }^{1,9}$
Semua pilihan tarapeutik yang digunakan pada pasien hipertiroidisme di luar kehamilan sebenarnya efektif digunakan pada wanita hamil, namun efek potensial pada janin mengharuskan adanya modifikasi dari pilihan tatalaksana hipertiroidisme selama kehamilan. Iodin radioaktif dikontraindikasikan selama kehamilan karena iodin mudah menembus plasenta. Pilihan terapi selama kehamilan adalah obat-obatan antitiroid, dimana konsumsi PTU lebih dianjurkan pada pasien hamil dibandingkan methimazole, terutama karena adanya risiko defek kulit kepala kongenital (kutis aplasia kongenital) terhadap janin yang ibunya menggunakan methimazole. Meskipun terdapat hubungan dengan restriksi pertumbuhan intrauterin atau IUGR dan juga kelahiran preterm, antagonis reseptor beta-adrenergik sering dipakai selama kehamilan, yaitu propanolol merupakan obat yang paling sering digunakan untuk tatalaksana thyroid storm, karena memiliki kemampuan mengurangi konversi $\mathrm{T}_{4}$ menjadi $\mathrm{T}_{3}$ di perifer. Jika propranolol dikontraindikasikan (misalnya pada pasien asma yang merupakan kontraindikasi relatif terhadap blokade reseptor beta-adrenergik nonspesifik) atau status hemodinamik pasien membutuhkan penggunaan antagonis reseptor beta-adrenergik kerja cepat, esmolol dipertimbangkan sebagai alternatif. Pada pasien dengan kardiomiopati yang signifikan, yang bisa sangat sensitif terhadap blokade reseptor betaadrenergik, esmolol dapat bermanfaat karena dosisnya dapat dengan mudah dititrasi sehingga menghasilkan efek yang diharapkan. ${ }^{1,9,10}$

Tatalaksana thyroid storm pada pasien hamil identik dengan pada pasien di luar masa kehamilan: Tindakan suportif umum (selimut pendingin, es, klorpromazin 25 - 50 mg intravena atau meperidin 25 $50 \mathrm{mg}$ intravena untuk menghilangkan menggigil, hidrasi intravena, penggantian glukosa dan elektrolit, asetaminofen untuk menatalaksana hipertermia, oksigen, glukokortikoid seperti dexamethasone dengan dosis 2-4 mg intravena per 8 jam dan hidrokortison $100 \mathrm{mg}$ intravena setiap 8 jamsebagai suplementasi karena adanya defisiensi relatif dan apabila ada hipotensi, serta multivitamin B-kompleks), reduksi sintesis dan sekresi hormon tiroid (obat-obatan antitiroid seperti PTU dengan loading dose 600 - 1200 
mg diikuti 200-400 mg oral setiap 6 sampai 8 jam atau methimazole 20 - $25 \mathrm{mg}$ per oral setiap 6 jam, iodin yaitu iodida natrium $1 \mathrm{~g}$ intravena dalam 12 jam atau larutan Lugol 4 - 8 tetes per oral setiap 6 - 8 jam atau larutan iodida kalium jenuh 5 tetes per oral setiap 6 jam, dan glukokortikoid), reduksi konversi $\mathrm{T}_{4}$ menjadi $\mathrm{T}_{3}$ (PTU, glukokortikoid, agen-agen kontras radiografik, dan propranolol 60 - $80 \mathrm{mg}$ oral per 4 jam atau 80 - $120 \mathrm{mg}$ per 6 jam), mengurangi efek metabolik hormon-hormon tiroid (agen-agen bloker reseptor beta-adrenergik seperti propranolol, dan esmolol sebagai alternatif), manuver terapeutik lainnya (pertukaran plasma, dantrolene), serta diagnosis dan koreksi dari penyakit dasar yang mencetuskan thyroid storm(misalnya pengobatan infeksi). Obat-obatan antitiroid (PTU) dapat diberikan melalui saluran nasogastrik, secara oral, atau rektal. Beta-blocker digunakan untuk gejala-gejala hiperadrenergik, dan dapat memperbaiki gagal jantung akibat takikardi tirotoksik atau depresi miokard. Infus esmolol atau beta-blocker intravena lainnya dapat digunakan dengan tujuan mempertahankan denyut jantung kurang dari seratus kali per menit. Dapat disimpulkan, tatalaksana thyroid stormterdiri atas tindakan suportif umum dan administrasi glukokortikoid, PTU, iodida natrium, dan beta-blocker. Tatalaksana iodin ditunda sampai 1 jam setelah administrasi tionamid (PTU) untuk mencegah peningkatan penggunaan iodin oleh kelenjar tiroid. Jika ada syok sirkulatori, vasopressor intravena berupa agonis reseptor alfa-adrenergik seperti fenilefrindapat dipakai. ${ }^{11,12}$

Risiko terjadinya thyroid storm pada periode perioperatif dapat diminimalisir dengan persiapan yang sesuai pada pasien-pasien dengan hipertiroid. Tujuan terapeutik preoperatif adalah inhibisi sintesis dan sekresi hormon tiroid pada pasien yang sudah memiliki riwayat hipertiroidisme dan untuk mengurangi vaskularitas kelenjar tiroid. Pada masa preoperatif, terapi utamanya kurang lebih sama, yakni antitiroid (terutama PTU), antagonis reseptor beta-adrenergik, glukokortikoid, dan iodin. Pasien dengan eksoftalmus sebaiknya mendapatkan perawatan untuk melindungi mata dan mencegah abrasi kornea, terutama apabila dilakukan anestesi umum. Pada beberapa pasien, blokade reseptor beta-adrenergik mungkin cukup untuk mencegah thyroid storm perioperatif, dan satu kelebihan dari antagonis reseptor beta-adrenergik dibandingkan obat-obatan antitiroid adalah waktu persiapan preoperatif yang dibutuhkan lebih singkat (dua minggu dibandingkan enam sampai delapan minggu dengan pengobatan antitiroid). Direkomendasikan pula preparasi dengan antagonis reseptor beta-adrenergik ditambah iodin sepuluh hari sebelum pembedahan. Wanita hipertiroid sebaiknya menerima suplementasi glukokortikoid karena mereka memiliki defisiensi relatif daripada simpanan glukokortikoid. Belum ada penelitian terandomisasi prospektif yang telah membandingkan efektivitas berbagai metode untuk persiapan preoperatif bagi pasien-pasien hipertiroid. Pendekatan klinis yang mungkin dilakukan mencakup penggunaan agen-agen terapeutik multipel seperti yang sudah dipaparkan sebelumnya, dengan dosis dititrasi terhadap respon klinis dari masing-masing pasien. Parameter klinis meliputi denyut nadi terinduksi-exercise, tremor halus, peningkatan berat badan dan pemulihan kekuatan otot. $^{1,9}$

Oleh karena banyaknya efek hormon tiroid pada tubuh, efek disfungsi tiroid sangat beragam dan secara signifikan memperumit prosedur pembedahan dan pemulihan postoperatif, sehingga sangat penting mendeteksi adanya kondisi disfungsi tiroid. Hal tersebut akan menjadi pertimbangan penting pada persiapan preoperatif. Pembedahan elektif sebaiknya jangan dilanjutkan tanpa preparasi preoperatif yang adekuat. Pada kasus-kasus yang mengharuskan pembedahan emergensi, dokter hendaknya menggunakan terapi-terapi untuk thyroid storm seperti yang didiskusikan sebelumnya. ${ }^{1,13}$

Persiapan preoperatif yang adekuat harus dilakukan untuk meminimalisir risiko thyroid storm perioeratif. Apabila memungkinkan, operasi sebaiknya ditunda sampai pasien eutiroid. Pasien hendaknya memiliki konsentrasi $T_{3}$ dan $T_{4}$ yang normal dan tidak memiliki takikardia saat istirahat atau resting tachycardia. Obat-obatan antitiroid dan antagonis beta-adrenergik dilanjutkan sampai pagi hari sebelum operasi, terutama administrasi PTU dan methimazole yang memiliki waktu paruh yang singkat. Apabila pembedahan emergensi harus dilakukan walaupun terdapat hipertiroidisme klinis, sirkulasi hiperdinamik dapat dikontrol dengan titrasi infus esmolol. 
Anestesiologis hendaknya mempersiapkan diri untuk menatalaksana thyroid storm perioeratif. ${ }^{1,2}$

Pada teknik anestesi belum ada studi terandomisasi prospektif yang telah mengevaluasi efektivitas maupun keamanan berbagai teknik anestesi pada pasien dengan hipertiroidisme. Baik anestesi umum maupun neuraxial dapat digunakan secara aman dan keputusan diambil berdasarkan kondisi individual pasien, yaitu faktor seperti adanya kelainan jalan nafas dan derajatnya, keterlibatan kardiak dan gangguan elektrolit. Sannaboraiah et al (2014) menyatakan bahwa secara umum pendekatan anestetik pada pembedahan abdominal bagi pasienpasien dengan hipertiroidisme tidak terkontrol yang direkomendasikan adalah kombinasi antara anestesi umum dengan teknik regional. ${ }^{5}$ Dikemukakan juga bahwa teknik regional saja, baik spinal maupun epidural, dapat menyediakan manajemen anestesi dan pembedahan yang sesuai pada pembedahanpembedahan urgen seperti laparatomi dan SC. Datta et al (2010) mengemukakan anestesia regional, terutama anestesi spinal dapat dihindari, khususnya untuk kelahiran caesarean apabila ibu mengonsumsi propranolol dosis tinggi akibat hipotensi berlebihan post-spinal. $^{6}$

Tujuan premedikasi pada pasien tirotoksik adalah untuk menghilangkan kecemasan dan mencegah aktivasi sistem saraf simpatik. Benzodiazepin seperti diazepam oral (5 sampai 10 mg) atau bloker adrenergik sentral seperti klonidin (3 sampai $5 \mu \mathrm{g} / \mathrm{kg}$ per oral) dapat diberikan. Antimuskarinik seperti atropine dan scopolamine tidak direkomendasikan, karena obat-obatan tersebut menyebabkan takikardi dan memengaruhi regulasi panas. Pada pasien hipertiroid diluar masa kehamilan telah ditekankan efektivitas daripada sedasi preoperatif yang dalam. Penggunaan rutin teknik ini pada pasien yang hamil tidak direkomendasikan karena adanya risiko aspirasi maternal dan depresi neonatal. $^{1,7}$

Beberapa karakteristik hipertiroidisme berikut ini mungkin dapat memengaruhi manajemen anestetik,
(1) sistem kardiovaskular yang hiperdinamik dan kemungkinan kardiomiopati, (2) obstruksi jalan napas partial yang diakibatkan pembesaran kelenjar tiroid, (3) kelemahan otot respiratori dan (4) abnormalitas elektrolit. Penggunaan obat-obatan yang dihubungkan dengan takikardi (ketamine, atropine) sebaiknya dihindari. Tirotoksikosis dihubungkan dengan peningkatan insiden miopati dan myasthenia gravis, sehingga agen-agen pemblokir neuromuskular atau Neuromuscular Blocking Agents (NMBs) harus diadministrasikan secara hati-hati. Hipertiroidisme tidak meningkatkan kebutuhan anestetik, tidak ada peningkatan pada konsenterasi alveolar minimal (MAC). ${ }^{1,2,9}$

Pada pelaksanaan intraoperatif, fungsi kardiovaskular dan suhu tubuh harus dimonitor ketat pada pasien-pasien dengan riwayat hipertiroidisme. Pasien-pasien hipertiroid yang tidak tertangani dengan baik dapat mengalami hipovolemi kronik dan rentan terhadap respon hipotensif yang berlebihan selama induksi anestesia.

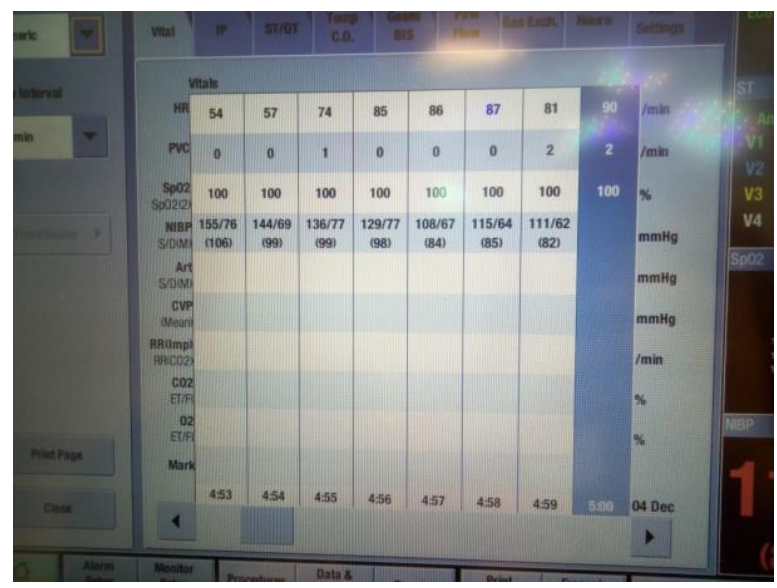

Gambar 1. Monitoring vital signs intraoperatif

Setelah selesai dilaksanakan operasi, pasien dipindahkan ke ROI dan pasien kembali mendapatkan obat-obatan PTU, lugol, dan propanolol secara enteral. Secara parenteral, pasien diberikan pula obatobatan ceftriaxon, ranitidin, paracetamol, asam traneksamat, vitamin $\mathrm{K}$, dan dexametason. 


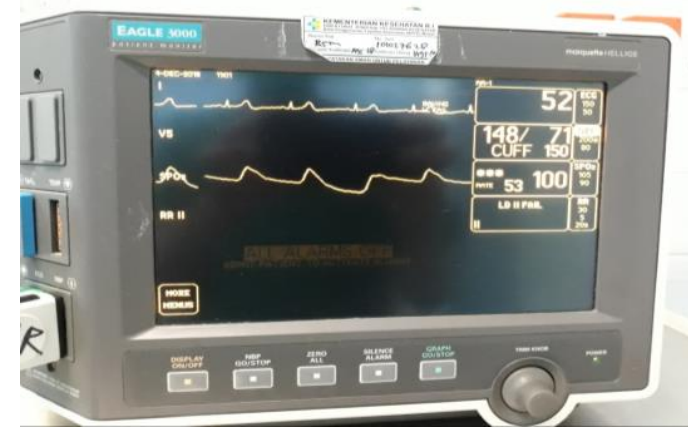

Gambar 2. Monitoring vital signs postoperatif

Ancaman paling serius pada pasien hipertiroid yang menjalani pembedahan, terutama pada fase postoperatif, adalah thyroid storm, yang ditandai dengan hiperpireksia, takikardi, perubahan kesadaran (seperti agitasi, delirium, koma), dan hipotensi. Onset thyroid storm ini umumnya 6 sampai 24 jam setelah pembedahan, tetapi dapat terjadi intraoperatif, menyerupai hipertermia malignan. Adanya kardiomiopati akibat hipertiroid selama masa kehamilan atau setelah melahirkan mungkin mengharuskan dilakukannya monitoring invasif dan penggunaan pengobatan multipel yang memerlukan titrasi. Berdasarkan kriteria the Critical Care Minimal Data Set (CCMDS), pasien memerlukan tingkat perawatan level 2, yakni membutuhkan optimalisasi preoperatif dan dukungan satu sistem organ pada fase postoperatif (sistem kardiovaskular). ${ }^{14}$

\section{DAFTAR PUSTAKA}

1. Chestnut DH, Wong CA, Tsen LC, Ngan Kee WD, Beilin Y, Mhyre JM. Obstetric anesthesia principles and practice. 5th edition. Philadelphia: Elsevier; 2014. p.1012-8.

2. Butterworth JF, Mackey DC, Wasnick JD. Morgan \& Mikhail's clinical anesthesiology. 5th edition. New York: McGraw-Hill Education; 2013. p.733-5.

3. Palace MR. Perioperative management of thyroid disfunction. Health Service Insights. 2017; 10:1178632916689677.

4. Varela A, Yuste A, Villazala R, Garrido J, Lorenzo A, Lopez E. Spinal anesthesia for emergency abdominal surgery in uncontrolled hyperthyroidism. Acta Anaesthesiol Scand. 2005; 49(1):100-3.
5. Sannaboraiah SK, Ramaswamy AH, Shaikh S. Thyroid disorders during pregnancy and anesthetic considerations. Anaesthesia, Pain, \& Intensive Care. 2014;18(3):302-7.

6. Datta S, Kodali BS, Segal S. Obstetric Anesthesia Handbook. 5th edition. New York: Elsevier; 2010. p.258.

7. Yao SFS. Yao \& Artusio's Anesthesiology: problem oriented patient management. 8th edition. Philadelphia: Lippincott Williams and Wilkins; 2016. p.754-66.

8. Sugiyama $\mathrm{Y}$, Tanaka $\mathrm{R}$, Yoshiyama $\mathrm{Y}$, Ichino $\mathrm{T}$, Hishinuma N, Shimizu S, et al. A case of sudden onset of thyroid storm just before cesarean section manifesting congestive heart failure and pulmonary edema. JA Clinical Reports. 2017;3(20):1-5.

9. Myers J, Mallaber D. Endocrine disease in pregnancy including diabetes mellitus, thyroid and adrenal disease. In: MacLennan K, O'Brien K, Macnab WR, eds. Core topics in obstetric anaesthesia. Cambridge: Cambridge University Press; 2015. p.371.

10. Wasson C, Kelly A, Ninan D, Tran Q. Absolute obstetric anesthesia review: the complete study guide for certification and recertification. Cham: Springer Nature Switzerland AG; 2019. p.40.

11. Hines RL, Marschall KE. Stoelting's anesthesia and co-exisiting disease. 4th edition. Philadelphia: Elsevier; 2013. p.237-9.

12. Arita N, Ward JL, Marik PE. Pituitary, adrenal, and thyroid diseases in the critically ill patient. In: Roberts PR, Rodd SR, eds. Comprehensive critical care: adult. 2nd edition. Mount Prospect: Society of Critical Care Medicine; 2017. p.806-9.

13. Swaminathan S, James RA, Chandran R, Joshi R. Anaesthetic implications of severe hyperthyroidism secondary to molar pregnancy: a case report and review of literature. Anesthesia: Essays and Researches. 2017;11(4):1116-7.

14. Wheatly S, O'Brien K. Maternal critical care. In: MacLennan K, O'Brien K, Macnab WR, eds. Core Topics in Obstetric Anaesthesia. Cambridge: Cambridge University Press; 2015. p.88. 